\title{
Insights into Pneumococcal Pathogenesis and Antibiotic Resistance
}

\author{
Eric S. Donkor1, Ebenezer V. Badoe ${ }^{2}$ \\ ${ }^{1}$ Department of Microbiology, College of Health Sciences, University of Ghana Medical School, Accra, Ghana \\ ${ }^{2}$ Department of Child Health, College of Health Sciences, University of Ghana Medical School, Accra, Ghana \\ Email: esampane-donkor@chs.ug.edu.gh
}

Received 10 March 2014; revised 22 April 2014; accepted 26 May 2014

Copyright (C) 2014 by authors and Scientific Research Publishing Inc.

This work is licensed under the Creative Commons Attribution International License (CC BY). http://creativecommons.org/licenses/by/4.0/

(c) $\underset{\mathrm{EY}}{\mathrm{EY}}$ Open Access

\begin{abstract}
Since its discovery in 1891 , the pneumococcus has been one of the most extensively studied microbes, and was involved in several historical findings such as the discovery of genetic material that was later shown to be DNA. The pneumococcus is part of the normal bacterial flora of the nasopharynx, but can on occasions progress to sterile sites of the body and cause invasive diseases. There are about one million new invasive pneumococcal infections every year, majority of which occur in the developing world where children $<5$ years are most affected. The burden of pneumococcal disease is further heightened by the increasing prevalence of multidrug resistance of the organism. The pneumococcus remains a pathogen of immense public health significance and understanding its biology, particularly the pathogenesis and antibiotic resistance is crucial to controlling pneumococcal disease.
\end{abstract}

\section{Keywords}

Pneumococcus, Antibiotic Resistance, Virulence, Penicillin, Genome

\section{Introduction}

The pneumococcus is part of the bacterial flora of the upper respiratory tract, and is also associated with several invasive diseases including meningitis, pneumonia and septicaemia. Worldwide, the annual incidence of invasive pneumococcal disease is about one million [1] [2], and the public health burden related to Streptococcus pneumoniae is heightened by the increasing resistance of the organism to essential antimicrobial drugs, particularly penicillin, cephalosporins and macrolides (http://spneumoniae.mlst.net/). Though pneumococcal conjugate vaccines have become available in many countries, they are not likely to eliminate pneumococcal disease. This is because the vaccines only cover a handful of serotypes [3], and the nonvaccine serotypes derive an ecological 
advantage from the removal of their competitors and have been increasing in carriage prevalence, disease and antibiotic resistance [4]-[6]. The pneumococcus is thus a pathogen of immense public health importance and understanding its biology, especially the pathogenesis and antibiotic resistance is of paramount importance. Information on pneumococcal pathogenesis and antibiotic resistance can provide clues for design of therapeutic and epidemiological control measures. This review paper therefore aims to provide insights into pneumococcal pathogenesis and antibiotic resistance.

\section{Historical, Microbial and Genomic Features of the Pneumococcus}

S. pneumoniae was first isolated in 1881 independently by Stenberg and Pasteur [7]. Each scientist was able to grow the organism in vitro and reported on its morphology as diplococcal with a capsule. Over the years the name of the organism has been altered several times. It was named Microbe septicemique du salive by Pasteur and Micrococcus pasteuri by Stenberg. Later it was named Pneumococcus and Diplococcus pneumoniae, and finally named Streptococcus pneumoniae [8]. Since its discovery, S. pneumoniae has been one of the most extensively studied organisms, and was involved in several historical findings; probably the most important was the discovery of genetic material that was later shown to be DNA. In 1928, Griffith observed that when heat-killed encapsulated S. pneumoniae and live strains constitutively lacking any capsule were concomitantly injected into mice, the non-encapsulated could be converted into encapsulated $S$. pneumoniae with the same capsular type as the heat killed strain [9]. About 16 years later, the nature of this "transforming principle", or carrier of genetic information, was shown to be DNA [10] [11]. Other important discoveries resulting from investigations of S. pneumoniae have been summarized by Austrian [12] and Watson et al. [13], and include:

- development of Gram staining in 1884.

- role of the bacterial capsule in resistance to phagocytosis in 1891.

- the quellung reaction in 1902.

- putative use of polysaccharide antigens as vaccines in 1927.

- therapeutic efficacy of penicillin in 1941.

- discovery of regulatory thymus-derived T lymphocytes in 1990.

S. pneumoniae is a Gram-positive, lancet-shaped bacteria usually occurring in pairs though they may also occur singly and in short chains. An important characteristic of the organism is the presence of a polysaccharide capsule which is the basis of over 90 different serotypes, which are further classified into 46 serotypes/groups based on antigenic similarities [14]-[16]. On an agar plate (usually blood agar), it grows as pinpoint, centrally depressed glistening colonies with alpha-haemolytic halos around the colonies. S. pneumoniae is a facultative anaerobe. However, $8 \%$ of clinical isolates particularly, serotypes 1, 3, 16, 28 and 34 require enrichment with carbon dioxide for growth [17]. The organism usually possesses an enzyme called autolysin that has the ability to disrupt and to disintegrate the cells in a process called autolysis. The autolytic activity of S. pneumoniae is often utilised as a diagnostic test for the organism, referred to as to as the bile solubility test. This test, together with optochin susceptibility, and some of the other phenotypic characteristics such as colony morphology and the presence of a capsule are used in the identification of S. pneumoniae [18].

After having a pioneering role in genetics through the discovery of DNA, the complete genome of a representative strain (TIGR4) of S. pneumoniae was published for the first time in 2001 [19]. Since the sequencing of the TIGR4 strain, over forty pneumococcal strains have been reported to be fully sequenced [20]. Information on the genome sequencing of various $S$. pneumoniae strains, including strains that have been fully sequenced and annotated, and others that are still in the process of being sequenced are reported on the websites of Wellcome Trust Sanger Institute (http://www.sanger.ac.uk/Projects/S_pneumoniae/) and National Centre for Biotechnology Information (http://www.ncbi.nlm.nih.gov/). The genomic features of two sequenced S. pneumoniae reference strains including TIGR4 and R6 that are used in most research laboratories are summarized in Table 1. The two strains have similar genome sizes, gene populations and GC contents. Both genomes display a high density of repeat elements including insertion, BOX, and RUPS that contribute to genomic plasticity [19] [21]. Both TIGR4 and R6 strains display several types of surface proteins and signal peptides appear to be the most abundant. Comparison of the TIGR4 and R6 genomes indicate that the genome structure is conserved throughout their lengths, but there are 12 clusters exclusive to TIGR4 and 6 clusters exclusive to R6. This is indicative of indels and also other regions between conserved flanks that differ between the TIGR4 and R6 genomes. A striking difference between the two genomes is that the R6 genome has a 7504 bp deletion in the capsule locus, 
Table 1. Genomic features of TIGR4 and R6 strains of Streptococcus pneumonia.

\begin{tabular}{ccc}
\hline Feature & TIGR4 genome & R6 genome \\
\hline Genome size & $2,160,837$ bp & $2,038,615$ bp \\
G + C content & $39.70 \%$ & $40 \%$ \\
No. of genes & 2236 & 2043 \\
Capsule & Serotype 4 & 7504 bp deletion \\
Sequence type & 205 & 128 \\
Surface-exposed proteins & & 10 \\
Choline binding & 15 & 13 \\
LPxTG & 19 & 42 \\
Lipoprotein & 47 & 153 \\
Signal peptide & 256 & 3 \\
Repeat elements & & 31 \\
IS elements & 105 & 115 \\
BOX elements & 105 & 84 \\
RUP elements & 111 & 58 \\
tRNA genes & 58 & 4 \\
rRNA genes & 4 & 31 \\
sRNA & & \\
\hline
\end{tabular}

Source: Tettelin et al. [19]; Hoskins et al. [21].

while the TIGR4 genome has a 13-gene cluster involved in capsular biosynthesis. This explains why TIGR4 is encapsulated while R6 is unencapsulated and is also avirulent.

\section{Pathogenesis of the Pneumococcus}

\subsection{Identification of Pneumococcus Virulence Determinants}

By definition, virulence determinants are molecules produced by pathogens that enable them to multiply and spread within a host in part by eluding host defences. Virulence determinants of pathogens are most often associated with disease in the host as they inhibit certain host functions. Traditionally, identification of virulence genes has relied on the characterization of individual defined mutants and their comparison with the parent strain in appropriate in vitro and in vivo assays. Though this approach has yielded useful information, it is costly and laborious, as analysis of large numbers of genes and consequently, the infection of numerous animals in infection models is required. New approaches that to some extent overcome these problems have been devised and include Signature Tagged Mutagenesis (STM), in vivo expression technology (IVET) and Microarray analysis. All three methods have been applied to identify virulence genes in S. pneumoniae [22]-[24].

Essentially, STM is a functional genomics approach that enables one to evaluate a large collection of potential mutants simultaneously in a single animal host, and then to identify mutants that fail to colonize host tissues [25]-[27]. In STM the mutagens are transposons that have been modified by incorporation of different DNA sequence tags, thus making it possible to monitor the progression of a particular mutant in a collection of other mutants [27]. Genes identified by STM can be categorised into three groups, including those whose functions have been defined, those with suspected functions and those whose function cannot be predicted. Several methods have been developed to help evaluate functions of genes in the second and third categories, which include in vitro procedures such starvation survival and growth rates in different media and in vivo procedures such as lethal dose determination. About $20 \%$ of pneumococcal genes screened by STM have indicated a potential role 
in virulence and encode transcriptional regulators, surface proteins and metabolic proteins [22]. IVET is a modification of STM and allows identification of promoters active in vivo by using genetic complementation of a conditionally lethal mutation, that is dependent on the fusion of an in vivo-expressed promoter to the coding sequence that complements the specific mutation [23]. Thus cloned promoters associated with the expression of a gene whose function is essential for survival within the host can be selected. Though this method has some drawbacks, a major advantage is the fact that a positive selection strategy can be used to isolate a gene of interest as opposed to STM. Additionally, unlike IVET, STM does not permit detection of virulence genes necessary for survival in vitro for the simple reason that gene knockouts results in defective growth of mutants [26]. Using IVET, Meng et al. [28] identified genes expressed specifically during S. pneumoniae infections in mice. Overall, fifteen genes were identified and encoded functions such as colonization and adherence, transportation of nutrients, energy metabolism, transcription regulation, DNA metabolism and cell wall biosynthesis.

Identification of virulence genes of $S$. pneumoniae and other pathogens can also be achieved through direct sequencing of their genomes followed by bioinformatic analysis of the sequence data. Within the sequence data, virulence genes or pathogenicity islands may be identified by looking for regions with DNA signatures (such as $\mathrm{G}+\mathrm{C}$ content or dinucleotide bias) that are different from other parts of the genome [29] [30]. Additionally, virulence genes can be identified through comparative analysis of sequenced genomes that are closely related (same species) or significantly different but cause similar diseases [31]. Through such comparison, and searching for genes that are co-regulated with known virulence factors, one can identify novel virulence factors.

\subsection{Virulence Determinants of the Pneumococcus}

The virulence determinants of the pneumococcus are numerous and cover a wide spectrum of microbial components. These virulence determinants are discussed extensively in this section, and are also summarized in Table 2 at the end of the section.

\subsubsection{Capsule}

The polysaccharide capsule of $S$. pneumoniae is a major virulence factor and has historically been demonstrated to be experimentally important for survival in mice by Avery and Goebel [32], Alonso De Velasco et al. [33] and Hammerschmidt et al. [34]. The polysaccharide capsule confers protection against phagocytosis and also inhibits complement activation by the alternative pathway [35]. Different pneumococcal capsular serotypes are known to vary in their capacity to resist phagocytosis which is mainly due to the biological properties of the capsular polysaccharide [36]. Virulence of S. pneumoniae mutants that differ only in the type of capsular polysaccharide expressed was studied by Kelly et al. [37] in the murine infection model. The investigators observed that the relative virulence of the mutants in relation to the parental strains (wild type) was determined mainly by the capsular type. However, the genetic background of the recipient strain was also of importance, indicating that non-capsular factors are also required for full virulence.

Table 2. Major virulence determinants of Streptococcus pneumonia.

\begin{tabular}{ccc}
\hline Virulence factor & Role in pathogenesis & Ref \\
\hline Capsule & Prevents opsonophagocytosis & {$[35]-[37]$} \\
Hyaluronidase & Helps in the spread of infection through host tissues & {$[42]-[44]$} \\
Pilus & Mediates attachment of pneumococci to host cells & {$[54]$} \\
IgA protease & Breaks down human IgA1 & {$[50][54]$} \\
Neuraminidase & Exposes pathogen binding sites in host by cleaving sialic acid & {$[51][52]$} \\
PspA & Causes inhibition of complement activation; binds to lactoferrin & {$[57]$} \\
PspC & Hinders formation of C3b; binds to slgA and factor H & {$[49]$} \\
Pneumolysin & Causes autolysis of pneumococci and release of pneumolysin & A
\end{tabular}




\subsubsection{Pili}

Pilus was recently reported among S. pneumoniae for the first time [38]. This pneumococcal pilus is encoded by the $r r$ A islet, which encodes three pilus subunit proteins, including RrgA, RrgB and RrgC. Experimental evidence indicate that this pilus play an important role in adhesion of the organism to humans, and is mediated mainly by RrgA [38]. The pneumococcal $r I r A$ islet is known to occur in about $30 \%$ of clinical isolates and seems to be associated with some clonal complexes such as CC156, CC236 and CC558 [39] [40]. More recently, another type of pneumococcal pilus (islet 2) has been reported [41]. This pilus has three structural proteins and has also been shown to be important for pneumococcal adherence to various cells such as A549 [41]. The distribution of islet 2 in pneumcocci appear to be different from that of islet $1(r I r A)$ as islet 2 occurs in some clones that lack islet 1 [39] [40].

\subsubsection{Hyaluronidase}

Pneumococcal strains isolated from cases of human meningitis and meningoencephalitis tend to have significantly higher hyaluronidase activity than strains isolated from cases of otitis media [42]. This indicates the role and importance of hyaluronidase in the pathogenesis of human pneumococcal meningitis or invasive disease. Hyaluronidase produced by $S$. pneumoniae degrades connective tissue of the host, and thereby facilitate spread or invasion of the organism. This observation indicates that $S$. pneumoniae strains with higher hyaluronidase activity spread more effectively as indicated by their ability to pass the blood-brain barrier [43] [44].

\subsubsection{Pneumococcal Specific Proteins}

S. pneumoniae has a vast range of proteins, but only a few actually contribute to the virulence of the organism. The proteins shown to contribute to pneumococcal virulence (pneumolysin, autolysins, neuraminidase, surface protein $\mathrm{A}$, surface protein $\mathrm{C}$, surface adhesion $\mathrm{A}$ and IgA protease) are described below:

\subsubsection{Pneumolysin}

Pneumolysin is the most studied pneumococcal protein and is a member of so called thiol activating haemolysins found in several Gram positive pathogens [45]-[47]. The protein contributes to virulence by diverse mechanisms, it:

- elicits the production of inflammatory cytokines like tumour necrosis factor alpha.

- inhibits the activity of cilia on human respiratory epithelial cells

- impedes the bactericidal activity and migration of neutrophils

- inhibits lymphocyte multiplication and antibody synthesis.

- activates the classical complement pathway in the absence of anti-toxin antibody

\subsubsection{Autolysins}

Three autolysins, LytA, LytB, and LytC are elaborated by S. pneumoniae. The major pneumococcal autolysin, LytA has been suggested to play a role in pneumococcal pathogenesis by releasing pneumolysin from the cytoplasm [48]. Loss of function of LytB and LytC has been shown to reduce the rate of pneumococcal colonisation in murine infections, while LytB which is highly expressed during exponential phase of growth, has been reported to be essential for cell separation [49].

\subsubsection{Neuraminidase}

Neuraminidase cleaves sialic acid from a wide variety of host molecules, thereby causing damage to host tissues. This action may result in exposing receptors for pneumococcal adhesins, thereby facilitating colonisation and invasion. S. pneumoniae has three genes encoding for neuraminidases namely, nanA, nanB, and nanC. Pettigrew et al. [50] investigated 342 pneumococcal isolates of different serotypes and sequence types, for the presence of nan genes; all the isolates carried the nanA gene; a majority carried the nanB gene, while about $50 \%$ of the isolates carried the nanC gene.

\subsubsection{Pneumococcal Surface Protein A (PspA)}

PspA functions as a specific receptor for lactoferrin, and thus plays an important role in the acquisition of iron by S. pneumoniae [51]. Mutagenesis studies have shown that PspA inhibits activation of the complement component C3 and thereby inhibits the complement cascade [52]. This interference with complement activation serves to facilitate pneumococcal survival and host invasion. 


\subsubsection{Pneumococcal Surface Protein C (PspC)}

PspC has some structural similarity with PspA and can cross-react with PspA [53]. However, unlike PspA, PspC is essential for pneumococcal carriage in addition to functional roles in virulence [54]. PspC binds to the polymeric immunoglobin receptor that normally binds secretory IgA [55] [56]. This binding enables translocation of S. pneumoniae across the respiratory epithelium. PspC also binds factor $\mathrm{H}$ which hinders the formation of C3b as well as activation of complement [57].

\subsubsection{Pneumococcal Surface Adhesin A (PsaA)}

PsaA is a component of an ABC-type manganese permease membrane transport system and has amino acid similarity to lipoprotein adhesins in some viridan streptococci [52]. PsaA and three other genes, psaB, psaC, and psaD form the psa operon. PsaA mutants are reported to express decreased adherence to mammalian cells [58] [59]. This observation has been attributed to the effect of lower expression of other adhesions as a result of loss of manganese transport. Evidence in support of this is the fact that when other genes of the same operon are mutated similar loss of adherence is observed [60].

\subsubsection{Pneumococcal Surface Adherence and Virulence Factor A (PavA)}

PavA is located to the cell outer surface of $S$. Pneumoniae though it lacks the classical cell wall determinants [61]. PavA has been demonstrated to be important in pneumococcal virulence, most probably without direct involvement in host cell interactions and inflammatory responses [62]. Most likely, PavA binds to fibronectin and regulates other virulence determinants of $S$. pneumoniae that are important in adherence and survival of the organism in vivo [62] [63]. Holmes et al. [61] investigated 64 S. pneumoniae isolates and observed PavA was present in all the isolates tested.

\subsubsection{Others Virulence Determinants}

Apart from the virulence determinants described in this section, several other pneumococcal virulence determinants such as beta-galactosidase [64] and enolase [65] have been proposed but are yet to be confirmed.

\subsection{Host-Pathogen Interaction in Invasive Pneumococcal Disease}

The first step in the pathogenesis of invasive pneumococcal disease involves translocation of the organism from the nasopharynx (where it occurs as a commensal) to disease sites including the lungs, blood and meninges [66]. At disease sites, progression of pneumococcal disease involves a complex interaction between pneumococcal virulence determinants and the host immune response which produces four major effects including adhesion, invasion, inflammation and shock [45] [54].

S. pneumoniae adheres to sialylated cell surface glycoconjugates and this is aided by neuraminidases of the organism that cleave terminal sialic acid exposing cryptic receptors [45]. In pneumonia, the attachment process may be augmented by prior influenza infection, which is mediated by a viral neuraminidase [67]. Invasion of pneumococci is mediated by cell wall phosphorylcholine interacting with the platelet activating factor receptor on eukaryotic cells, and only transparent pneumococci are known to bind effectively to these receptors [67] [68]. Human C-reactive protein binds to cell wall phosphorylcholine resulting in complement activation via the classical pathway which leads to inflammation and recruitment of leukocytes [69] [70]. As leukocytes begin to control pneumococcal multiplication, dying bacteria release cell walls, pneumolysins, and other components, leading to greater inflammation, cytotoxic effects on host cells, and shock [67] [71]. In pneumonia, the interaction of leukocytes, the numerous bacterial cells and excessive fluid define the presence of the disease [71], which is detectable by a chest X-ray. Bacteraemia can occur in some cases of pneumococcal pneumonia, and the most important factor in pneumococcal bacteraemia is the antiphagocytic capsule of the organism which may lead to high bacteria titers. In bacteraemia, pneumococci in the blood can cross the blood-brain barrier and enter the cerebrospinal fluid and brain parenchyma causing meningitis. Like other meningeal pathogens, the pneumococcus recognizes the blood-brain barrier by its interactions with laminin receptor on the vascular endothelium [45].

\section{Antibiotic Resistance of the Pneumococcus}

\subsection{Epidemiology and Mechanisms of Pneumococcal Antibiotic Resistance}

Antibiotic resistance is currently a major public health problem especially, with important human pathogens uch 
as S. pneumoniae. The problem has been attributed to high use of antibiotics which puts selective pressure on bacteria leading to the emergence of resistant strains. Several risk factors for increased resistance of S. pneumoniae have been identified and include: exposure to specific serotypes and clones, hospitalisation, residence in an urban area, day care attendance, previous exposure to antibiotics, HIV infection and exposure to a class of drug to which resistance can be easily selected from a susceptible population of organisms [72] [73]. Expansion of resistant clones, as well as serotype replacement favouring resistant serotypes and clones, have also contributed significantly to the dissemination of antibiotic resistance [74] [75]. Generally, pneumococcal serotypes 6B, 23F, 14, 9V, 19A and 19F, as well as some pneumococcal clones such as ST 63, ST 81, ST 41, ST 75 and ST 185 are relatively more antibiotic resistant [76]-[78].

Since its discovery in 1928, penicillin has always been the drug of choice for treating pneumococcal diseases [79] [80]. The mechanism of penicillin action involves inhibition of the formation of peptidoglycan cross-links in the bacterial cell wall, through the $\beta$-lactam moiety that binds to the bacterial enzyme DD-transpeptidase [81]. This action weakens the cell wall of the bacterium and causes autolysis. Much of the recent interest in the epidemiology of pneumococci involves tracing the spread of penicillin resistance. The first case of S. pneumoniae resistance to penicillin was detected in 1967 [82], and since then pneumococcal resistance to penicillin has escalated reaching high rates in both developed and developing countries (Table 3). The mechanism of resistance to penicillin and other beta-lactam antibiotics in pneumococci is due to altered penicillin binding proteins (PBP). There are six variants of the penicillin binding proteins, including five high molecular weight variants and one low molecular weight variant [83]. The high molecular weight variants are in two classes, which are Class A (PBP1a, PBP1b, PBP2a) and Class B (PBP2b and PBP2x). Mutations occurring at penicillin binding domains of PBP can decrease their affinity for penicillin, and thereby make the organism resistant [83] [84]. PBP2b and PBP2x are the primary resistance determinants and are spread among pneumococci through intraspecies or interspecies recombination [85] [86].

The increasing penicillin-resistant pneumococcus has led to the high usage of non-beta lactam antibiotics for treating pneumococcal diseases. However, the increased usage of such drugs has also resulted in high levels of pneumococcal resistance (Table 3). Currently, macrolides appear to be the most used non-beta lactam antibiotic for treating pneumococcal infections. Like tetracycline and chloramphenicol, macrolides act at the ribosomal level and inhibit proteins synthesis. Macrolides binds to the 23S rRNA molecule (in the 50S subunit) of the bacterial ribosome and blocks exit of the growing peptide chain [87] [88]. On the other hand, chloramphenicol inhibits peptidyl transferase activity and therefore elongation of the protein chain, while tetracycline blocks attachment of the transfer RNA-amino acid to the ribosome, thereby inhibiting codon-anticodon interaction [87] [89]. Resistance to macrolides in S. pneumoniae occurs by two types of mechanisms resulting in two types of resistance phenotypes, namely, $\mathrm{MLS}_{\mathrm{B}}$ and $\mathrm{M}$ phenotypes. For $\mathrm{MLS}_{\mathrm{B}}$ phenotype, resistance is mediated by methylation of the ribosomal 23S RNA (drug target) and is associated with the ermB gene, that encodes an rRNA methylase and confers resistance to macrolides, lincosamides and streptogramin B [90]. In the case of the M-phenotype, resistance occurs by drug efflux from cells mediated by a membrane protein encoded by mefA, that confers resistance to the 14- and 15-membered macrolides [91]. M phenotype pneumococci have been reported to be relatively predominant in some countries such as Scotland [92] and United States [93], while the $\mathrm{MLS}_{\mathrm{B}}$ phenotype occurs more commonly, in Italy [94], Belgium [95], and Germany [96]. Chromosomal mutations can affect the sensitivity of antibiotic targets, and this is the most common mechanism of resistance to a number of non-beta-lactam antibiotics, including quinolones, trimethoprim and rifampin (Table 4). Through genetic transformation, resistance to these drugs can be spread to other pneumococci. In the case of macrolides, tetracycline and chloramphenicol, the resistance determinants are carried on conjugative transposons, which are usually of the Tn916-1545 family [97] [98]. Conjugative transposons can easily spread resistance determinants as they are involved in movement between replicative DNA species, and can also be transferred by recombination, particularly in cases where conjugative transposons lose their conjugal transfer genes. Transposition of pneumococcal Tn916 elements can result in the formation of composite transposons such as Tn5253 or plasmids integrated elements that carry several resistant genes [99].

Development of multiple drug resistance in pneumococci represents a major challenge in the treatment of pneumococcal infections. Multi-drug resistant isolates display resistance to three or more classes of antimicrobial agents, and the first pneumococcal isolate fulfilling this criterion was detected in Johannesburg in 1977 [100]. The high occurrence of pneumococcal antibiotic resistant genes coupled with the ease with which such genes can spread horizontally, have enhanced global dissemination of successful multi-drug resistant pneumococcal 
Table 3. Prevalence of Streptococcus pneumoniae antibiotic resistance.

\begin{tabular}{|c|c|c|c|c|c|c|c|c|c|}
\hline \multirow[t]{2}{*}{ Country } & \multirow[t]{2}{*}{$\mathbf{N}$} & \multicolumn{7}{|c|}{ Prevalence of antibiotic resistance (\%) } & \multirow[t]{2}{*}{ Reference } \\
\hline & & pen & amp & tet & chlo & ery & cot & ctx & \\
\hline Ghana & 35 & 20 & 48 & 62 & 11 & 28 & 84 & 11 & [111] \\
\hline Nigeria & 23 & 0 & - & 0 & 0 & 0 & 100 & 0 & [112] \\
\hline Gambia & 127 & 2 & 0 & 53 & 11 & - & 20 & 0 & [113] \\
\hline Burkina Faso & 64 & 22 & - & - & 4 & - & - & - & [114] \\
\hline Togo & 102 & 12 & - & - & 7 & - & - & - & [114] \\
\hline Ivory Coast & 482 & 11 & - & - & - & 6 & - & - & [115] \\
\hline Uganda & 30 & 83 & - & - & 7 & - & - & 0 & [116] \\
\hline Venezuela Warao & 161 & 11 & - & 11 & - & 11 & - & - & [117] \\
\hline China & 61 & 43 & - & - & - & 100 & 100 & 13 & [118] \\
\hline Thailand & 72 & 41 & - & - & - & 30 & 55 & - & [119] \\
\hline Bangladesh & 139 & 0 & - & - & 6 & - & 32 & - & [120] \\
\hline Nepal & 33 & 4 & - & - & 0 & 7 & 68 & 4 & [121] \\
\hline Pakistan & 15 & 26 & - & - & 26 & - & 93 & - & [122] \\
\hline Sri Lanka & 24 & 91 & - & - & 26 & 61 & 74 & 48 & [123] \\
\hline Belgium & 148 & 12 & - & 24 & 3 & - & 19 & 3 & [124] \\
\hline France & 443 & 48 & - & 41 & 15 & - & 42 & 11 & [124] \\
\hline Germany & 530 & 6 & - & 11 & 2 & - & 15 & 1 & [124] \\
\hline United States & 39,495 & 21 & - & 16 & - & 29 & 28 & - & [125] \\
\hline Mozambique & 9 & 13 & - & - & 0 & - & - & - & [126] \\
\hline Israeli Bedouin & 321 & 22 & - & - & - & - & - & - & [127] \\
\hline
\end{tabular}

Data is absent. pen—penicillin; amp—ampicillin; tet— tetracycline; chlo—chloramphenicol; ery—erythromycin; cot—cotrimoxazole; ctx—cefotaxime.

strains [101]. Currently, it is estimated that up to $40 \%$ of $S$. pneumoniae display multi-drug resistant phenotypes, which is highly variable among countries [72].

\subsection{Evolution of Pneumococcal Antibiotic Resistance}

Recently, the most important event that has affected the evolution of pneumococcal antibiotic resistance has been the introduction of pneumococcal vaccines. Following introduction of the 7-valent Pneumococcal Conjugate Vaccine (PCV7), it was observed that generally, there has been an increase in antibiotic resistance as well as diseases and carriage associated with pneumococcal serotypes not contained in the vaccine [5] [6]. This phenomenon is referred to as serotype replacement, and a notable pneumococcal serotype associated with serotype replacement is 19A [6] [102]. Given that pneumococcal serotype 19A is particularly associated with antibiotic resistance [76]-[78], serotype replacement involving this serotype could be an important factor affecting prevalence of pneumococcal antibiotic resistance. Brueggmann et al. [103] showed that the vaccine related increase in antibiotic resistance of serotype 19A was due to an expansion of the clonal cluster-CC199 that was present before introduction of the vaccine and also the emergence of a strain of ST695 that previously carried a pneumococcal serotype 4 capsule. A recent introduction of 13-valent Pneumococcal Conjugate Vaccine (PCV13) which contains serotype 19A can prevent the serotype replacement effect of serotype 19A. However, this would further affect the epidemiology of pneumococcal antibiotic resistance, disease and carriage through serotype replacement of other pneumococcal serotypes. 
Table 4. Mechanisms of action and resistance of non beta-lactam antibiotics in relation to the pneumococcus.

\begin{tabular}{ccc}
\hline Antibiotic & Mechanism of action & Resistance mechanism \\
\hline Macrolides & Blocks exit of the growing peptide chain in protein & Methylation of 23S rRNA by erm gene [128] \\
synthesis [87] [88] & Inhibits DNA gyrase [88] & drug efflux mediated by mefF or mefA genes [129] \\
Quinolones & Mutations in gyrA or parC genes [130] \\
Tetracycline & $\begin{array}{c}\text { Inhibits codon-anticodon interaction in } \\
\text { protein synthesis [87] [89] }\end{array}$ & drug efflux mediated by pmrA gene [131] \\
thloramphenicol & Inhibits peptidyl transferase [87] [89] & Inactivation of chloramphenicol by cat gene [133] \\
Trimethoprim & Inhibits dihydrofolate reductase [87]-[89] & Mutation in dihydrofolate reductase gene [133] \\
Sulfamethoxazole & Inhibits dihydropteroate synthetase [87]-[89] & Mutation in dihydropteroate synthase gene [133] \\
Rifampin & Inhibits bacterial RNA polymerase [87]-[89] & Mutation in RNA polymearse gene [134]
\end{tabular}

In the last decade, molecular typing and whole genome sequencing of the pneumococcus have provided unprecedented insights into the evolution of pneumococcal antibiotic resistance. Hanage et al. [104] analyzed 1930 pneumococcal MLST genotypes from six housekeeping genes and 94 genotypes from related streptococcal species. They identified four pneumococcal clusters, including three homogeneous clusters and one cluster that represented admixture of different streptococci (mosaic genotypes). Relatively, the latter was significantly associated with higher antibiotic resistance not only for penicillin, but also for other drugs, including, erythromycin, tetracycline, chloramphenicol, and cefotaxime. Strain in this "admixture" cluster appeared more able to accept extraneous DNA and are thus of particular interest with respect to strains that are more likely to be virulent and/or antibiotic resistant. The findings of this study show that recombination is a major factor driving pneumococcal antibiotic resistance which is not surprising as pneumococcal evolution is dominated by recombination. Using MLST data, Feil et al. [105] showed that the rate of recombination in the pneumococcus was ten times greater than the rate of mutation, while for the meningococcus, the rate of mutation was five times greater than the rate of mutation. The high rate of pneumococcal recombination has been elucidated by the whole genome sequencing of a collection of 240 strains of a single clone, ST 81 [106]. This showed that over 700 recombinational events had occurred in this pneumococcal clone or lineage and $74 \%$ of the genome length had undergone recombination in at least one strain. Recently, Wyres et al. [107] used whole genome sequencing to study the evolution of antibiotic resistance of a global collection of 426 strains of the pneumococcal clone ST 81 isolated between 1937 and 2007. The study showed that one of the earliest known penicillin-resistant pneumococci, isolated in 1967 in Australia, was the probable ancestor of the ST 81 clone, since about 95\% of its genes were very similar to those of the ST 81 clone. This study also showed that the ST 81 clone was highly promiscuous with its DNA, donating several antibiotic resistant genes, as well as virulence and cell adherence genes to many genotypically diverse pneumococci. It appears that only the ST 81 clone has received such a high level of genome sequencing investigations among pneumococcal strains. Similar sequencing studies on other antibiotic-resistant pneumococcal clones would provide further insights into the evolution of pneumococcal antibiotic resistance.

\subsection{Pneumococcal Antibiotic Resistance and the Implications for Clinical Practice}

The evolution of pneumococcal antibiotic resistance has important implications for clinical practice. Consequently, antibiotic treatment guidelines for pneumococcal infections especially, meningitis and pneumonia are updated in response to the changes in resistance patterns. According to the current Infectious Disease Society of America (IDSA) guidelines on the management of community-acquired pneumonia in adults, a macrolide is recommended as a single regimen for outpatient treatment [108]. However, using macrolides as empirical regimen in areas where macrolides resistance rates are higher than 25\% should be discouraged [108]. This implies that macrolides such as erythromycin should probably not be used for treatment of pneumococcal infections in countries such as China, Ghana, Thailand, United States and Sri Lanka (Table 3). It is recommended that cefuroxime is administered to patients with risk for antibiotic-resistant pneumococcal infection [108]. However, 
again the relatively high prevalence of cefuroxime resistance in some countries does not make this feasible [109]. For pneumococcal meningitis, it recommended that a third generation cephalosporin such as cefotaxime or ceftriaxone is administered [110]. However, due to the increasing pneumococcal resistance to these drugs, IDSA recommends addition of vancomycin [110]. It is important to note that pneumococcal resistance to cotrimoxazole and tetracycline have reached high levels globally (Table 3), and therefore these antibiotics should not be used to treat pneumococcal infections. Generally, the disparities in pneumococcal antibiotic resistance among different countries appear to be wide (Table 3), and therefore there is the need to develop antibiotic treatment guidelines based on local or in-country resistance data.

\section{Conclusion}

Pneumococcal pathogenesis involves a complex interaction between pneumococcal virulence determinants and the host immune response which produces four major effects including adhesion, invasion, inflammation and shock. Many pneumococcal virulence determinants have been identified, and the pneumococcal capsule remains the most important virulence. Several aspects of pneumococcal pathogenesis are still not fully understood, for example, the factors involved in the translocation of the organism from the nasopharynx to disease sites such as the lung are not clear. Pneumococcal resistance to antibiotics is reaching alarming levels and antibiotics such as cotrimoxazole and tetracycline provide little benefit in antimicrobial therapy. Recently, the most important event that has affected the evolution of pneumococcal antibiotic resistance has been the introduction of pneumococcal conjugate vaccines. This has caused serotype replacement, with non-vaccine serotypes becoming more prevalent in disease, carriage and antibiotic resistance. With the ability of the pneumococcus to evade several classes of antibiotic and also conjugate polysaccharide vaccines, the pneumococcus has proven to be a particularly formidable public health enemy. Advances in molecular biology especially, whole genome sequencing has provided invaluable insights into pneumococcal pathogenesis and evolution of pneumococcal antibiotic resistance. Further pneumococcal studies in this area could provide insight into novel strategies for antimicrobial agents and more effective pneumococcal vaccines.

\section{Acknowledgements}

We thank authors of the various papers included in this review article.

\section{Conflict of Interest}

None declared.

\section{References}

[1] Black, R.E., Cousens, S., Johnson, H.L., Lawn, J.E., Rudan, I., Bassani, D.G., Jha, P., Campbell, H., Walker, C.F., Cibulskis, R., Eisele, T., Liu, L. and Mathers, C. (2010) Global, Regional, and National Causes of Child Mortality in 2008: A Systematic Analysis. The Lancet, 375, 1969-1987. http://dx.doi.org/10.1016/S0140-6736(10)60549-1

[2] O’Brien, K.L., Wolfson, L.J, Watt, J.P., Henkle, E. and Deloria-Knoll, M. (2009) Burden of Disease Caused by Streptococcus pneumoniae in Children Younger than 5 Years: Global Estimates. The Lancet, 374, 893-902. http://dx.doi.org/10.1016/S0140-6736(09)61204-6

[3] Selman, S., Hayes, D., Perin, L.A. and Hayes, W.S. (2000) Pneumococcal Conjugate Vaccine for Young Children. Managed Care, 9, 49-52.

[4] Pelton, S.I., Huot, H., Finkelstein, J.A., Bishop, C.J., Hsu, K.K., Kellenberg, J., Huang, S.S., Goldstein, R. and Hanage, W.P. (2007) Emergence of 19A as Virulent and Multidrug Resistant Pneumococcus in Massachusetts Following Universal Immunization of Infants with Pneumococcal Conjugate Vaccine. Pediatric Infectious Disease Journal, 26, 468472. http://dx.doi.org/10.1097/INF.0b013e31803df9ca

[5] Singleton, R.J., Hennessy, T.W., Bulkow, L.R., Hammitt, L.L., Zulz, T., Hurlburt, D.A., Butler, J.C., Rudolph, K. and Parkinson, A. (2007) Invasive Pneumococcal Disease Caused by Nonvaccine Serotypes among Alaska Native Children with High Levels of 7-Valent Pneumococcal Conjugate Vaccine Coverage. JAMA, 297, 1784-1792. http://dx.doi.org/10.1001/jama.297.16.1784

[6] Donkor, E.S., Dayie, N.T.K.D. and Badoe, E.V. (2013) Vaccination against Pneumococcus in West Africa: Perspectives and Prospects. International Journal of General Medicine, 6, 1-8.

[7] White, B.A. (1938) The Biology of Pneumococcus. Harvard University Press, Cambridge. 
[8] Bergey, D.H., Buchanan, R.E. and Gibbons, N.E. (1974) Bergey’s Manual of Determinative Bacteriology. Williams \& Wilkins Co., Baltimore.

[9] Griffith, F. (1928) The Significance of Pneumococcal Types. Journal of Hygiene, 27, 113-159. http://dx.doi.org/10.1017/S0022172400031879

[10] Steinman, R.M. and Moberg, C.L. (1994) A Triple Tribute to the Experiment That Transformed Biology. Journal of Experimental Medicine, 179, 379-384.

[11] Avery, O.T., Macleod, C.M. and Mccarty, M. (1995) Studies on the Chemical Nature of the Substance Inducing Transformation of Pneumococcal Types. Induction of Transformation by a Deoxyribonucleic Acid Fraction Isolated from Pneumococcus Type III. 1944. Molecular Medicine, 1, 344-365.

[12] Austrian, R. (1981) Some Observations on the Pneumococcus and on the Current Status of Pneumococcal Disease and Its Prevention. Clinical Infectious Diseases, 3, S1-S17. http://dx.doi.org/10.1093/clinids/3.Supplement_1.S1

[13] Watson, D.A., Musher, D.M., Jacobson, J.W. and Verhoef, J. (1993) A Brief History of the Pneumococcus in Biomedical Research: A Panoply of Scientific Discovery. Clinical Infectious Diseases, 17, 913-924. http://dx.doi.org/10.1093/clinids/17.5.913

[14] Henrichsen, J. (1995) Six Newly Recognized Types of Streptococcus pneumoniae. Journal of Clinical Microbiology, 33, 2759-2762.

[15] Park, I.H., Pritchard, D.G., Cartee, R., Brandao, A., Brandileone, M.C.C. and Nahm, M.H. (2007) Discovery of a New Capsular Serotype (6C) within Serogroup 6 of Streptococcus pneumoniae. Journal of Clinical Microbiology, 45, 12251233. http://dx.doi.org/10.1128/JCM.02199-06

[16] Calix, J.J. and Nahm, M.H. (2010) A New Pneumococcal Serotype, 11E, Has a Variably Inactivated wcjE Gene. The Journal of Infectious Diseases, 202, 29-38. http://dx.doi.org/10.1086/653123

[17] Austrian, R. and Collins, P. (1966) Importance of Carbon Dioxide in the Isolation of Pneumococci. Journal of Bacteriology, 92, 1281-1284.

[18] Werno A.M. and Murdoch, D.R. (2008) Laboratory Diagnosis of Invasive Pneumococcal Disease. Clinical Infectious Diseases, 46, 926-932. http://dx.doi.org/10.1086/528798

[19] Tettelin, H., Nelson, K.E., Paulsen, I.T., Eisen, J.A., Read, T.D., Peterson, S., Heidelberg, J., Deboy, R.T., Haft, D.H., Dodson, R.J., Durkin, A.S., Gwinn, M., Kolonay, J.F., Nelson, W.C., Peterson, J.D., Umayam, L.A., White, O., Salzberg, S.L., Lewis, M.R., Radune, D., Holtzapple, E., Khouri, H., Wolf, A.M., Utterback, T.R., Hansen, C.L., Mcdonald, L.A., Feldblyum, T.V., Angiuoli, S., Dickinson, T., Hickey, E.K., Holt, I.E., Loftus, B.J., Yang, F., Smith, H.O., Venter, J.C., Dougherty, B.A., Morrison, D.A., Hollingshead, S.K. and Fraser, C.M. (2001) Complete Genome Sequence of a Virulent Isolate of Streptococcus pneumoniae. Science, 293, 498-506. http://dx.doi.org/10.1126/science.1061217

[20] Donati, C., Hiller, N.L., Tettelin, H., Muzzi, A., Croucher, N.J., Angiuoli, S.V., Oggioni, M., Hotopp, J.C.D., Hu, F.Z., Riley, D.R., Covacci, A., Mitchell, T.J., Bentley, S.D., Kilian, M., Ehrlich, G.D., Rappuoli, R., Moxon, E.R. and Masignani, V. (2010) Structure and Dynamics of the Pan-Genome of Streptococcus pneumoniae and Closely Related Species. Genome Biology, 11, R107. http://dx.doi.org/10.1186/gb-2010-11-10-r107

[21] Hoskins, J., Alborn, W.E., Arnold, J., Blaszczak, L.C., Burgett, S., Dehoff, B.S., Estrem, S.T., Fritz, L., Fu, D.J., Fuller, W., Geringer, C., Gilmour, R., Glass, J.S., Khoja, H., Kraft, A.R., Lagace, R.E., Leblanc, D.J., Lee, L.N., Lefkowitz, E.J., Lu, J., Matsushima, P., Mcahren, S.M., Mchenney, M., Mcleaster, K., Mundy, C.W., Nicas, T.I., Norris, F.H., O’gara, M., Peery, R.B., Robertson, G.T., Rockey, P., Sun, P.M., Winkler, M.E., Yang, Y., Young-Bellido, M., Zhao, G., Zook, C.A., Baltz, R.H., Jaskunas, S.R., Rosteck, P.R., Skatrud, P.L. and Glass, J.I. (2001) Genome of the Bacterium Streptococcus pneumoniae Strain R6. Journal of Bacteriology, 183, 5709-5717. http://dx.doi.org/10.1128/JB.183.19.5709-5717.2001

[22] Hava, D.L. and Camilli, A. (2002) Large-Scale Identification of Serotype 4 Streptococcus pneumoniae Virulence Factors. Molecular Microbiology, 45, 1389-1406.

[23] Silby, M.W. and Levy, S.B. (2004) Use of in Vivo Expression Technology to Identify Genes Important in Growth and Survival of Pseudomonas fluorescens Pf0-1 in Soil: Discovery of Expressed Sequences with Novel Genetic Organization. Journal of Bacteriology, 186, 7411-7419. http://dx.doi.org/10.1128/JB.186.21.7411-7419.2004

[24] Obert, C., Sublett, J., Kaushal, D., Hinojosa, E., Barton, T., Tuomanen, E.I. and Orihuela, C.J. (2006) Identification of a Candidate Streptococcus pneumoniae Core Genome and Regions of Diversity Correlated with Invasive Pneumococcal Disease. Infection and Immunity, 74, 4766-4777. http://dx.doi.org/10.1128/IAI.00316-06

[25] Hensel, M., Shea, J.E., Gleeson, C., Jones, M.D., Dalton, E. and Holden, D.W. (1995) Simultaneous Identification of Bacterial Virulence Genes by Negative Selection. Science, 269, 400-403. http://dx.doi.org/10.1126/science.7618105

[26] Autret, N. and Charbit, A. (2005) Lessons from Signature-Tagged Mutagenesis on the Infectious Mechanisms of Pathogenic Bacteria. FEMS Microbiology Reviews, 29, 703-717. http://dx.doi.org/10.1016/j.femsre.2004.10.006

[27] Choi, K.H. and Kim, K.J. (2009) Signature-Tagged Mutagenesis: Technical Advances in a Negative Selection Method 
for Virulence Gene Identification. The Journal of Microbiology and Biotechnology, 19, 217-228.

[28] Meng, J.P., Yin, Y.B., Zhang, X.M., Huang, Y.S., Lan, K., Cui, F. and Xu, S.X. (2008) Identification of Streptococcus pneumoniae Genes Specifically Induced in Mouse Lung Tissues. Canadian Journal of Microbiology, 54, 58-65. http://dx.doi.org/10.1139/W07-117

[29] Karlin, S. (2001) Detecting Anomalous Gene Clusters and Pathogenicity Islands in Diverse Bacterial Genomes. Trends in Microbiology, 9, 335-343. http://dx.doi.org/10.1016/S0966-842X(01)02079-0

[30] Van Passel, M.W., Bart, A., Thygesen, H.H., Luyf, A.C., Van Kampen, A.H. and van der Ende, A. (2005) An Acquisition Account of Genomic Islands Based on Genome Signature Comparisons. BMC Genomics, 6, 163. http://dx.doi.org/10.1186/1471-2164-6-163

[31] Subramanian, G., Mural, R., Hoffman, S.L., Venter, J.C. and Broder, S. (2001) Microbial Disease in Humans: A Genomic Perspective. Journal of Molecular Diagnostics, 6, 243-252.

[32] Avery, O.T. and Goebel, W.F. (1931) Chemo-Immunological Studies on Conjugated Carbohydrate-Proteins: The Immunological Specifity of an Antigen Prepared by Combining the Capsular Polysaccharide of Type III Pneumococcus with Foreign Protein. The Journal of Experimental Medicine, 54, 437-447. http://dx.doi.org/10.1084/jem.54.3.437

[33] De Velasco, E.A., Verheul, A.F., Verhoef, J. and Snippe, H. (1995) Streptococcus pneumoniae: Virulence Factors, Pathogenesis, and Vaccines. Microbiological Reviews, 59, 591-603.

[34] Hammerschmidt, S., Wolff, S., Hocke, A., Rosseau, S., Müller, E. and Rohde, M. (2005) Illustration of Pneumococcal Polysaccharide Capsule during Adherence and Invasion of Epithelial Cells. Infection and Immunity, 73, 4653-4667. http://dx.doi.org/10.1128/IAI.73.8.4653-4667.2005

[35] Hyams, C., Camberlein, E., Cohen, J.M., Bax, K. and Brown J.S. (2010) The Streptococcus pneumoniae Capsule Inhibits Complement Activity and Neutrophil Phagocytosis by Multiple Mechanisms. Infection and Immunity, 78, 704-715. http://dx.doi.org/10.1128/IAI.00881-09

[36] Magee, A.D. and Yother, J. (2001) Requirement for Capsule in Colonization by Streptococcus pneumoniae. Infection and Immunity, 69, 3755-3761. http://dx.doi.org/10.1128/IAI.69.6.3755-3761.2001

[37] Kelly, T., Dillard, J.P. and Yother, J. (1994) Effect of Genetic Switching of Capsular Type on Virulence of Streptococcus pneumoniae. Infection and Immunity, 62, 1813-1819.

[38] Barocchi, M.A., Ries, J., Zogaj, X., Hemsley, C., Albiger, B., Kanth, A., Dahlberg, S., Fernebro, J., Moschioni, M., Masignani, V., Hultenby, K., Taddei, A.R., Beiter, K., Wartha, F., Von Euler, A., Covacci, A., Holden, D.W., Normark, S., Rappuoli, R. and Henriques-Normark, B. (2006) A Pneumococcal Pilus Influences Virulence and Host Inflammatory Responses. Proceedings of the National Academy of Sciences of the United States of America, 103, 2857-2862. http://dx.doi.org/10.1073/pnas.0511017103

[39] Sjöström, K., Blomberg, C., Fernebro, J., Dagerhamn, J., Morfeldt, E., Barocchi, M.A., Browall, S., Moschioni, M., Andersson, M., Henriques, F., Albiger, B., Rappuoli, R., Normark, S. and Henriques-Normark, B. (2007) Clonal Success of Piliated Penicillin Nonsusceptible Pneumococci. Proceedings of the National Academy of Sciences of the United States of America, 104, 12907-12912. http://dx.doi.org/10.1073/pnas.0705589104

[40] Moschioni, M., Donati, C., Muzzi, A., Masignani, V., Censini, S., Hanage, W.P., Bishop, C.J., Reis, J.N., Normark, S., Henriques-Normark, B., Covacci, A., Rappuoli, R. and Barocchi, M.A. (2008) Streptococcus pneumoniae Contains 3 rlrA Pilus Variants That Are Clonally Related. The Journal of Infectious Diseases, 197, 888-896. http://dx.doi.org/10.1086/528375

[41] Bagnoli, F., Moschioni, M., Donati, C., Dimitrovska, V., Ferlenghi, I., Facciotti, C., Muzzi, A., Giusti, F., Emolo, C., Sinisi, A., Hilleringmann, M., Pansegrau, W., Censini, S., Rappuoli, R., Covacci, A., Masignani, V. and Barocchi, M.A. (2008) A Second Pilus Type in Streptococcus pneumoniae Is Prevalent in Emerging Serotypes and Mediates Adhesion to Host Cells. Journal of Bacteriology, 190, 5480-5492. http://dx.doi.org/10.1128/JB.00384-08

[42] Volkova, M.O., Kostiukova, N.N. and Kvetnaia, A.S. (1994) The Role of Hyaluronidase in the Occurrence of a Generalized Pneumococcal Infection. Zh Mikrobiol Epidemiol Immunobiol, 1, 118-122.

[43] Kvetnaia, A.S., Kostiukova, N.N., Ivanova, V.V., Volkova, M.O. and Loskutova, N.G. (1995) Streptococcus pneumoniae Adhesion. Zh Mikrobiol Epidemiol Immunobiol, 5, 23-26.

[44] Zwijnenburg, P.J., van der Poll, T., Florquin, S., van Deventer, S.J., Roord, J.J. and van Furth, A.M. (2001) Experimental Pneumococcal Meningitis in Mice: A Model of Intranasal Infection. The Journal of Infectious Diseases, 183, 1143-1146. http://dx.doi.org/10.1086/319271

[45] Kadioglu, A., Taylor, S., Iannelli, F., Pozzi, G., Mitchell, T.J. and Andrew, P.W. (2002) Upper and Lower Respiratory Tract Infection by Streptococcus pneumoniae Is Affected by Pneumolysin Deficiency and Differences in Capsule Type. Infection and Immunity, 70, 2886-2890. http://dx.doi.org/10.1128/IAI.70.6.2886-2890.2002

[46] Cockeran, R., Durandt, C., Feldman, C., Mitchell, T.J. and Anderson, R. (2002) Pneumolysin Activates the Synthesis and Release of Interleukin-8 by Human Neutrophils in Vitro. The Journal of Infectious Diseases, 186, 562-565. 
http://dx.doi.org/10.1086/341563

[47] Neeleman, C., Klaassen, C.H.W., Klomberg, D.M., de Valk, H.A. and Mouton, J.W. (2004) Pneumolysin Is a Key Factor in Misidentification of Macrolide-Resistant Streptococcus pneumoniae and Is a Putative Virulence Factor of $S$. mitis and Other Streptococci. Journal of Clinical Microbiology, 42, 4355-4357. http://dx.doi.org/10.1128/JCM.42.9.4355-4357.2004

[48] Lock, R.A., Hansman, D. and Paton, J.C. (1992) Comparative Efficacy of Autolysin and Pneumolysin as Immunogens Protecting Mice against Infection by Streptococcus pneumoniae. Microbial Pathogenesis, 12, 137-143. http://dx.doi.org/10.1016/0882-4010(92)90116-6

[49] Gosink, K.K., Mann, E.R., Guglielmo, C., Tuomanen, E.I. and Masure, H.R. (2000) Role of Novel Choline Binding Proteins in Virulence of Streptococcus pneumoniae. Infection and Immunity, 68, 5690-5695. http://dx.doi.org/10.1128/IAI.68.10.5690-5695.2000

[50] Pettigrew, M.M., Fennie, K.P., York, M.P., Daniels, J. and Ghaffar, F. (2006) Variation in the Presence of Neuraminidase Genes among Streptococcus pneumoniae Isolates with Identical Sequence Types. Infection and Immunity, 74, 3360-3365. http://dx.doi.org/10.1128/IAI.01442-05

[51] Hammerschmidt, S., Bethe, G., Remane, P.H. and Chhatwal, G.S. (1992) Identification of Pneumococcal Surface Protein A as a Lactoferrin-Binding Protein of Streptococcus pneumoniae and Their Use in Functional Studies and Cloning of the pspA Gene. Journal of Bacteriology, 174, 610-618.

[52] Fenno, J.C., Leblanc, D.J. and Fives-Taylor, P. (1989) Nucleotide Sequence Analysis of a Type 1 Fimbrial Gene of Streptococcus sanguis FW213. Infection and Immunity, 57, 3527-3533.

[53] Briles, D.E., Hollingshead, S.K., Swiatlo, E., Brooks-Walter, A., Szalai, A., Virolainen, A., Mcdaniel, L.S., Benton, K. A., White, P., Prellner, K., Hermansson, A., Aerts, P.C., van Dijk, H. and Crain, M.J. (1997) PspA and PspC: Their Potential for Use as Pneumococcal Vaccines. Microbial Drug Resistance, 3, 401-408. http://dx.doi.org/10.1089/mdr.1997.3.401

[54] Gilliespie, S.H. and Balakrishnan, I. (2000) Pathogenesis of Pneumococcal Infection. Journal of Medical Microbiology, 49, 1057-1067.

[55] Rosenow, C., Ryan, P., Weiser, J.N., Johnson, S., Fontan, P., Ortqvist, A. and Masure, H.R. (1997) Contribution of Novel Choline-Binding Proteins to Adherence, Colonization and Immunogenicity of Streptococcus pneumoniae. Molecular Microbiology, 25, 819-829. http://dx.doi.org/10.1111/j.1365-2958.1997.mmi494.x

[56] Hammerschmidt, S., Talay, S.R., Brandtzaeg, P. and Chhatwal, G.S. (2001) SpsA, a Novel Pneumococcal Surface Protein with Specific Binding to Secretory Immunoglobulin A and Secretory Component. Molecular Microbiology, 40, 1273-1287.

[57] Dave, S., Brooks-Walter, A., Pangburn, M.K. and McDaniel, L.S. (2001) PspC, a Pneumococcal Surface Protein, Binds Human Factor H. Infection and Immunity, 69, 3435-3437. http://dx.doi.org/10.1128/IAI.69.5.3435-3437.2001

[58] Berry, A.M. and Paton, J.C. (1996) Sequence Heterogeneity of PsaA, a 37-Kilodalton Putative Adhesin Essential for Virulence of Streptococcus pneumoniae. Infection and Immunity, 64, 5255-5262.

[59] Anderton, J.M., Rajam, G., Romero-Steiner, S., Summer, S., Kowalczyk, A.P., Carlone, G.M., Sampson, J.S. and Ades, E.W. (2007) E-Cadherin Is a Receptor for the Common Protein Pneumococcal Surface Adhesin A (PsaA) of Streptococcus pneumoniae. Microbial Pathogenesis, 42, 225-236. http://dx.doi.org/10.1016/j.micpath.2007.02.003

[60] Johnston, J.W., Myers, L.E., Ochs, M.M., Benjamin, W.H., Briles, D.E. and Hollingshead, S.K. (2004) Lipoprotein PsaA in Virulence of Streptococcus pneumoniae: Surface Accessibility and Role in Protection from Superoxide. Infection and Immunity, 72, 5858-5867. http://dx.doi.org/10.1128/IAI.72.10.5858-5867.2004

[61] Holmes, A.R., Mcnab, R., Millsap, K.W., Rohde, M., Hammerschmidt, S., Mawdsley, J.L. and Jenkinson, H.F. (2001) The pavA Gene of Streptococcus pneumoniae Encodes a Fibronectin-Binding Protein That Is Essential for Virulence. Molecular Microbiology, 41, 1395-1408. http://dx.doi.org/10.1046/j.1365-2958.2001.02610.X

[62] Pracht, D., Elm, C., Gerber, J., Bergmann, S., Rohde, M., Seiler, M., Kim, K.S., Jenkinson, H.F., Nau, R. and Hammerschmidt, S. (2005) PavA of Streptococcus pneumoniae Modulates Adherence, Invasion, and Meningeal Inflammation. Infection and Immunity, 73, 2680-2689. http://dx.doi.org/10.1128/IAI.73.5.2680-2689.2005

[63] Jensch, I., Gámez, G., Rothe, M., Ebert, S., Fulde, M., Somplatzki, D., Bergmann, S., Petruschka, L., Rohde, M., Nau, R. and Hammerschmidt, S. (2010) PavB Is a Surface-Exposed Adhesin of Streptococcus pneumoniae Contributing to Nasopharyngeal Colonization and Airways Infections. Molecular Microbiology, 77, 22-43. http://dx.doi.org/10.1111/j.1365-2958.2010.07189.x

[64] Terra, V.S., Homer, K.A., Rao, S.G., Andrew, P.W. and Yesilkaya, H. (2010) Characterization of Novel $\beta$-Galactosidase Activity That Contributes to Glycoprotein Degradation and Virulence in Streptococcus pneumoniae. Infection and Immunity, 78, 348-357. http://dx.doi.org/10.1128/IAI.00721-09

[65] Bergmann, S., Rohde, M., Chhatwal, G.S. and Hammerschmidt, S. (2001) $\alpha$-Enolase of Streptococcus pneumoniae Is a 
Plasmin(ogen)-Binding Protein Displayed on the Bacterial Cell Surface. Molecular Microbiology, 40, 1273-1287. http://dx.doi.org/10.1046/j.1365-2958.2001.02448.x

[66] Bogaert, D., de Groot, R. and Hermans, P.W. (2004) Streptococcus pneumoniae Colonisation: The Key to Pneumococcal Disease. The Lancet Infectious Diseases, 4, 144-154. http://dx.doi.org/10.1016/S1473-3099(04)00938-7

[67] Opal, S.M. and van der Poll, T. (2009) Pathogenesis, Treatment, and Prevention of Pneumococcal Pneumonia. The Lancet, 374, 1543-1556.

[68] Cundell, D.R., Pearce, B.J., Sandros, J., Naughton, A.M. and Masure, H.R. (1995) Peptide Permeases from Streptococcus pneumoniae Affect Adherence to Eucaryotic Cells. Infection and Immunity, 63, 2493-2498.

[69] Moreillon, P. and Majcherczyk, P.A. (2003) Proinflammatory Activity of Cell-Wall Constituents from Gram-Positive Bacteria. Scandinavian Journal of Infectious Diseases, 35, 632-641. http://dx.doi.org/10.1080/00365540310016259

[70] Suresh, M.V., Singh, S.K., Ferguson Jr., D.A. and Agrawal, A. (2006) Role of the Property of C-Reactive Protein to Activate the Classical Pathway of Complement in Protecting Mice from Pneumococcal Infection. The Journal of Immunology, 176, 4369-4374. http://dx.doi.org/10.4049/jimmunol.176.7.4369

[71] Tuomanen, E.I., Austrian, R. and Masure, H.R. (1995) Pathogenesis of Pneumococcal Infection. The New England Journal of Medicine, 332, 1280-1284. http://dx.doi.org/10.1056/NEJM199505113321907

[72] Van Bambeke, F., Reinert, R.R., Appelbaum, P.C., Tulkens, P.M. and Peetermans, W.E. (2007) Multidrug-Resistant Streptococcus pneumoniae Infections: Current and Future Therapeutic Options. Drugs, 67, 2355-2382. http://dx.doi.org/10.2165/00003495-200767160-00005

[73] Blossom, D.B., Cordeiro, S.M., Bajaksouzian, S., Joloba, M.L., Kityo, C., Whalen, C.C., Salata, R.A. and Jacobs, M.R. (2007) Characterization of Penicillin Intermediate Serotypes of Streptococcus pneumoniae Carried by Human Immunodeficiency Virus-Infected Adults and Healthy Children in Uganda. Microbial Drug Resistance, 13, 21-28. http://dx.doi.org/10.1089/mdr.2006.9993

[74] Hanage, W.P. (2008) Serotype-Specific Problems Associated with Pneumococcal Conjugate Vaccination. Future Microbiology, 3, 23-30. http://dx.doi.org/10.2217/17460913.3.1.23

[75] Paradiso, P.R. (2011) Advances in Pneumococcal Disease Prevention: 13-Valent Pneumococcal Conjugate Vaccine for Infants and Children. Clinical Infectious Diseases, 52, 1241-1247. http://dx.doi.org/10.1093/cid/cir142

[76] Klugman, K.P. (2002) The Successful Clone: The Vector of Dissemination of Resistance in Streptococcus pneumoniae. Journal of Antimicrobial Chemotherapy, 50, 1-6. http://dx.doi.org/10.1093/jac/dkf500

[77] Smith, A.M. and Klugman, K.P. (1997) Three Predominant Clones Identified within Penicillin-Resistant South African Isolates of Streptococcus pneumoniae. Microbial Drug Resistance, 3, 385-389. http://dx.doi.org/10.1089/mdr.1997.3.385

[78] Paul, J., Bates, J., Kimari, J. and Gilks, C. (1996) Serotypes and Antibiotic Susceptibilities of Streptococcus pneumoniae in Nairobi, Kenya. Journal of Infection, 32, 139-142. http://dx.doi.org/10.1016/S0163-4453(96)91374-2

[79] Abraham, E.P., Chain, E., Fletcher, C.M., Florey, H.W., Gardner, A.D., Heatley, N.G. and Jennings, M.A. (1992) Further Observations on Penicillin. 1941. European Journal of Clinical Pharmacology, 42, 3-9.

[80] Skovbjerg, S., Söderström, A., Hynsjö, L., Normark, B.H., Ekdahl, K. and Åhrén, C. (2013) Low Rate of Pneumococci Non-Susceptible to Penicillin in Healthy Swedish Toddlers. Scandinavian Journal of Infectious Diseases, 45, 279-284. http://dx.doi.org/10.3109/00365548.2012.734919

[81] Yocum, R.R., Rasmussen, J.R. and Strominger, J.L. (1980) The Mechanism of Action of Penicillin. Penicillin Acylates the Active Site of Bacillus stearothermophilus D-Alanine Carboxypeptidase. Journal of Biological Chemistry, 255, 3977-3986.

[82] Hansman, D. and Bullen, M.M. (1967) A Resistant Pneumococcus. The Lancet, 2, 264-265. http://dx.doi.org/10.1016/S0140-6736(67)92346-X

[83] Zerfass, I., Hakenbeck, R. and Denapaite, D. (2009) An Important Site in PBP2x of Penicillin-Resistant Clinical Isolates of Streptococcus pneumoniae: Mutational Analysis of Thr338. Antimicrobial Agents and Chemotherapy, 53, 1107-1115. http://dx.doi.org/10.1128/AAC.01107-08

[84] Grebe, T. and Hakenbeck, R. (1996) Penicillin-Binding Proteins 2b and 2x of Streptococcus pneumoniae Are Primary Resistance Determinants for Different Classes of Beta-Lactam Antibiotics. Antimicrobial Agents and Chemotherapy, 40, 829-834.

[85] Coffey, T.J., Daniels, M., Mcdougal, L.K., Dowson, C.G., Tenover, F.C. and Spratt, B.G. (1995) Genetic Analysis of Clinical Isolates of Streptococcus pneumoniae with High-Level Resistance to Expanded-Spectrum Cephalosporins. Antimicrobial Agents and Chemotherapy, 39, 1306-1313. http://dx.doi.org/10.1128/AAC.39.6.1306

[86] Coffey, T.J., Dowson, C.G., Daniels, M. and Spratt, B.G. (1993) Horizontal Spread of an Altered Penicillin-Binding Protein 2B Gene between Streptococcus pneumoniae and Streptococcus oralis. FEMS Microbiology Letters, 110, 335- 
339. http://dx.doi.org/10.1111/j.1574-6968.1993.tb06345.x

[87] Wise, R. (1999) A Review of the Mechanism of Action and Resistance of Antimicrobial Agents. Canadian Respiratory Journal, 6, 20-22.

[88] Walker, C.B., Karpinia, K. and Baehni, P. (2004) Chemotherapeutics: Antibiotics and Other Antimicrobials. Periodontology 2000, 36, 146-165. http://dx.doi.org/10.1111/j.1600-0757.2004.03677.x

[89] Newton, B.A. (1995) Mechanisms of Antibiotic Action. Ann Rev of Microbiol, 19, 209-240. http://dx.doi.org/10.1146/annurev.mi.19.100165.001233

[90] Leclercq, R. and Courvalin, P. (1991) Intrinsic and Unusual Resistance to Macrolide, Lincosamide, and Streptogramin Antibiotics in Bacteria. Antimicrobial Agents and Chemotherapy, 35, 1273-1276.

[91] Sutcliffe, J., Grebe, T., Tait-Kamradt, A. and Wondrack, L. (1996) Detection of Erythromycin-Resistant Determinants by PCR. Antimicrobial Agents and Chemotherapy, 40, 2562-2566.

[92] Amezaga, M.R., Carter, P.E., Cash, P. and McKenzie, H. (2002) Molecular Epidemiology of Erythromycin Resistance in Streptococcus pneumoniae Isolates from Blood and Noninvasive Sites. Journal of Clinical Microbiology, 40, 33133318. http://dx.doi.org/10.1128/JCM.40.9.3313-3318.2002

[93] Doern, G.V., Heilmann, K.P., Huynh, H.K., Rhomberg, P.R., Coffman, S.L. and Brueggemann, A.B. (2001) Antimicrobial Resistance among Clinical Isolates of Streptococcus pneumoniae in the United States during 1999-2000, Including a Comparison of Resistance Rates Since 1994-1995. Antimicrobial Agents and Chemotherapy, 45, 1721-1729. http://dx.doi.org/10.1128/AAC.45.6.1721-1729.2001

[94] Oster, P., Zanchi, A., Cresti, S., Lattanzi, M., Montagnani, F., Cellesi, C. and Rossolini, G.M. (1999) Patterns of Macrolide Resistance Determinants among Community-Acquired Streptococcus pneumoniae Isolates over a 5-Year Period of Decreased Macrolide Susceptibility Rates. Antimicrobial Agents and Chemotherapy, 43, 2510-2512.

[95] Descheemaeker, P., Chapelle, S., Lammens, C., Hauchecorne, M., Wijdooghe, M., Vandamme, P., Ieven, M. and Goossens, H. (2000) Macrolide Resistance and Erythromycin Resistance Determinants among Belgian Streptococcus pyogenes and Streptococcus pneumoniae Isolates. Journal of Antimicrobial Chemotherapy, 45, 167-173. http://dx.doi.org/10.1093/jac/45.2.167

[96] Reinert, R.R., Simic, S., Al-Lahham, A., Reinert, S., Lemperle, M. and Lutticken, R. (2001) Antimicrobial Resistance of Streptococcus pneumoniae Recovered from Outpatients with Respiratory Tract Infections in Germany from 1998 to 1999: Results of a National Surveillance Study. Journal of Clinical Microbiology, 39, 1187-1189. http://dx.doi.org/10.1128/JCM.39.3.1187-1189.2001

[97] Cochetti, I., Tili, E., Vecchi, M., Manzin, A., Mingoia, M., Varaldo, P.E. and Montanari, M.P. (2007) New Tn916Related Elements Causing erm(B)-Mediated Erythromycin Resistance in Tetracycline-Susceptible Pneumococci. Journal of Antimicrobial Chemotherapy, 60, 127-131. http://dx.doi.org/10.1093/jac/dkm120

[98] Cochetti, I., Tili, E., Mingoia, M., Varaldo, P.E. and Montanari, M.P. (2008) erm(B)-Carrying Elements in Tetracycline-Resistant Pneumococci and Correspondence between Tn1545 and Tn6003. Antimicrobial Agents and Chemotherapy, 52, 1285-1290. http://dx.doi.org/10.1128/AAC.01457-07

[99] Henderson-Begg, S.K., Roberts, A.P. and Hall, L.M.C. (2009) Diversity of Putative Tn5253-Like Elements in Streptococcus pneumoniae. International Journal of Antimicrobial Agents, 33, 364-367. http://dx.doi.org/10.1016/j.ijantimicag.2008.10.002

[100] Jacobs, M.R., Koornhof, H.J., Robins-Browne, R.M., Stevenson, C.M., Vermaak, Z.A., Freiman, I., Miller, G.B., Witcomb, M.A., Isaacson, M., Ward, J.I. and Austrian, R. (1978) Emergence of Multiply Resistant Pneumococci. New Engl J Med, 299, 735-740. http://dx.doi.org/10.1056/NEJM197810052991402

[101] Maiden, M.C. (1998) Horizontal Genetic Exchange, Evolution, and Spread of Antibiotic Resistance in Bacteria. Clinical Infectious Diseases, 27, S12-S20. http://dx.doi.org/10.1086/514917

[102] Weinberger, D.M., Malley, R. and Lipsitch, M. (2011) Serotype Replacement in Disease after Pneumococcal Vaccination. The Lancet, 378, 1962-1973. http://dx.doi.org/10.1016/S0140-6736(10)62225-8

[103] Brueggemann, A.B., Pai, R., Crook, D.W. and Beall, B. (2007) Vaccine Escape Recombinants Emerge after Pneumococcal Vaccination in the United States. PLoS Pathogens, 3, e168. http://dx.doi.org/10.1371/journal.ppat.0030168

[104] Hanage, W.P., Fraser, C., Tang, J., Connor, T.R. and Corander, J. (2009) Hyper-Recombination, Diversity, and Antibiotic Resistance in Pneumococcus. Science, 324, 1454-1457. http://dx.doi.org/10.1126/science.1171908

[105] Feil, E.J., Smith, J.M., Enright, M.C. and Spratt, B.G. (2000) Estimating Recombinational Parameters in Streptococcus pneumoniae from Multilocus Sequence Typing Data. Genetics, 154, 1439-1450.

[106] Croucher, N.J., Harris, S.R., Fraser, C., Quail, M.A., Burton, J., van der Linden, M., Mcgee, L., von Gottberg, A., Song, J.H., Ko, K.S., Pichon, B., Baker, S., Parry, C.M., Lambertsen, L.M., Shahinas, D., Pillai, D.R., Mitchell, T.J., Dougan, G., Tomasz, A., Klugman, K.P., Parkhill, J., Hanage, W.P. and Bentley, S.D. (2011) Rapid Pneumococcal Evolution in 
Response to Clinical Interventions. Science, 331, 430-434. http://dx.doi.org/10.1126/science.1198545

[107] Wyres, K.L., Lambertsen, L.M., Croucher, N.J., McGee, L., von Gottberg, A., Linares, J., Jacobs, M.R., Kristinsson, K. G., Beall, B.W., Klugman, K.P., Parkhill, J., Hakenbeck, R., Bentley, S.D. and Brueggemann, A.B. (2013) Pneumococcal Capsular Switching: A Historical Perspective. The Journal of Infectious Diseases, 207, 439-449. http://dx.doi.org/10.1093/infdis/jis703

[108] Woodhead, M., Blasi, F., Ewig, S., Garau, J., Huchon, G., Leven, M., Ortqvist, A., Schaberg, T., Torres, A., van der Heijden, G., Read, R. and Verheij, T.J. (2011) Guidelines for the Management of Adult Lower Respiratory Tract Infections-Full Version. Clinical Microbiology and Infection, 17, 1-59.

[109] Hung, I.F., Tantawichien, T., Tsai, Y.H., Patil, S. and Zotomayor, R. (2013) Regional Epidemiology of Invasive Pneumococcal Disease in Asian Adults: Epidemiology, Disease Burden, Serotype Distribution, and Antimicrobial Resistance Patterns and Prevention. International Journal of Infectious Diseases, 17, e364-373. http://dx.doi.org/10.1016/j.ijid.2013.01.004

[110] Tunkel, A.R, Hartman, B.J., Kaplan, S.L., Kaufman, B.A., Roos, K.L., Scheld, W.M. and Whitley, R.J. (2004) Practice Guidelines for the Management of Bacterial Meningitis. Clinical Infectious Diseases, 39, 1267-1284. http://dx.doi.org/10.1086/425368

[111] Donkor, E.S., Newman, M.J., Oliver-Commey, J., Bannerman, E., Dayie, N.T.K.D. and Badoe, E.V. (2010) Invasive Disease and Paediatric Carriage of Streptococcus pneumoniae in Ghana. Scandinavian Journal of Infectious Diseases, 42, 254-259. http://dx.doi.org/10.3109/00365540903490000

[112] Falade, A.G., Lagunju, I.A., Bakare, R.A., Odekanmi, A.A. and Adegbola, R.A. (2009) Invasive Pneumococcal Disease in Children Aged<5 Years Admitted to 3 Urban Hospitals in Ibadan, Nigeria. Clinical Infectious Diseases, 48, 190-196. http://dx.doi.org/10.1086/596500

[113] Antonio, M., Dada-Adegbola, H., Biney, E., Awine, T., O’Callaghan, J., Pfluger, V., Enwere, G., Okoko, B., Oluwalana, C., Vaughan, A., Zaman, S.M., Pluschke, G., Greenwood, B.M., Cutts, F. and Adegbola, R.A. (2008) Molecular Epidemiology of Pneumococci Obtained from Gambian Children Aged 2-29 Months with Invasive Pneumococcal Disease during a Trial of a 9-Valent Pneumococcal Conjugate Vaccine. BMC Infectious Diseases, 8, 81. http://dx.doi.org/10.1186/1471-2334-8-81

[114] Traore, Y., Tameklo, T.A., Njanpop-Lafourcade, B.M., Lourd, M., Yaro, S., Niamba, D., Drabo, A., Mueller, J.E., Koeck, J.L. and Gessner, B.D. (2009) Incidence, Seasonality, Age Distribution, and Mortality of Pneumococcal Meningitis in Burkina Faso and Togo. Clinical Infectious Diseases, 48, 181-189. http://dx.doi.org/10.1086/596498

[115] Kacou-N'douba, A., Guessennd-Kouadio, N., Kouassi-M’Bengue, A. and Dosso, M. (2004) Evolution of Streptococcus pneumoniae Antibiotic Resistance in Abidjan: Update on Nasopharyngeal Carriage, from 1997 to 2001. Médecine et Maladies Infectieuses, 34, 83-85. http://dx.doi.org/10.1016/j.medmal.2003.02.001

[116] Kisakye, A., Makumbi, I., Nansera, D., Lewis, R., Braka, F., Wobudeya, E., Chaplain, D., Nalumansi, E., Mbabazi, W. and Gessner, B.D. (2009) Surveillance for Streptococcus pneumoniae Meningitis in Children under 5 Years of Age: Implications for Immunization in Uganda. Clinical Infectious Diseases, 48, S153-S161. http://dx.doi.org/10.1086/596495

[117] Rivera-Olivero, I.A., Bogaert, D., Bello, T., del Nogal, B., Sluijter, M., Hermans, P.W. and de Waard, J.H. (2007) Pneumococcal Carriage among Indigenous Warao Children in Venezuela: Serotypes, Susceptibility Patterns, and Molecular Epidemiology. Clinical Infectious Diseases, 45, 1427-1434. http://dx.doi.org/10.1086/522984

[118] Liu, C., Xiong, X., Xu, W., Sun, J., Wang, L. and Li, J. (2013) Serotypes and Patterns of Antibiotic Resistance in Strains Causing Invasive Pneumococcal Disease in Children Less than 5 Years of Age. PLoS ONE, 8, e54254. http://dx.doi.org/10.1371/journal.pone.0054254

[119] Baggett, H.C., Peruski, L.F., Olsen, S.J., Thamthitiwat, S., Rhodes, J., Dejsirilert, S., Wongjindanon, W., Dowell, S.F., Fischer, J.E., Areerat, P., Sornkij, D., Jorakate, P., Kaewpan, A., Prapasiri, P., Naorat, S., Sangsuk, L., Eampokalap, B., Moore, M.R., Carvalho, G., Beall, B., Ungchusak, K. and Maloney, S.A. (2009) Incidence of Pneumococcal Bacteremia Requiring Hospitalization in Rural Thailand. Clinical Infectious Diseases, 48, S65-S74. http://dx.doi.org/10.1086/596484

[120] Saha, S.K, Naheed, A., Arifeen. S.E., Islam, M., Al-Emran, H., Amin, R., Fatima, K., Brooks, W.A., Breiman, R.F., Sack, D.A. and Luby, S.P. (2009) Surveillance for Invasive Streptococcus pneumoniae Disease among Hospitalized Children in Bangladesh: Antimicrobial Susceptibility and Serotype Distribution. Clinical Infectious Diseases, 48, S75S81. http://dx.doi.org/10.1086/596544

[121] Shah, A.S., Knoll, M.D., Sharma, P.R., Moisi, J.C., Kulkarni, P., Lalitha, M.K., Steinhoff, M. and Thomas, K. (2009) Invasive Pneumococcal Disease in Kanti Children's Hospital, Nepal, as Observed by the South Asian Pneumococcal Alliance Network. Clinical Infectious Diseases, 48, S123-S128. http://dx.doi.org/10.1086/596490

[122] Zaidi, A.K.M., Khan, H., Lasi, R. and Mahesar, W. (2009) Surveillance of Pneumococcal Meningitis among Children in Sindh, Southern Pakistan. Clinical Infectious Diseases, 48, S129-S135. http://dx.doi.org/10.1086/596491 
[123] Batuwanthudawe, R., Karunarathne, K., Dassanayake, M., de Silva, S., Lalitha, M.K., Thomas, K., Steinhoff, M. and Abeysinghe, N. (2009) Surveillance of Invasive Pneumococcal Disease in Colombo, Sri Lanka. Clinical Infectious Diseases, 48, S136-S140. http://dx.doi.org/10.1086/596492

[124] Reinert, R.R., Reinert, S., van der Linden, M., Cil, M.Y., Al-Lahham, A. and Appelbaum, P. (2005) Antimicrobial Susceptibility of Streptococcus pneumoniae in Eight European Countries from 2001 to 2003. Antimicrobial Agents and Chemotherapy, 49, 2903-2913. http://dx.doi.org/10.1128/AAC.49.7.2903-2913.2005

[125] Jenkins, S.G., Brown, S.D. and Farrell, D.J. (2008) Trends in Antibacterial Resistance among Streptococcus pneumonie Isolated in the USA: Update from PROTEKT US Years 1-4. Annals of Clinical Microbiology and Antimicrobials, 7, 1. http://dx.doi.org/10.1186/1476-0711-7-1

[126] Roca, A., Bassat, Q., Morais, L., Machevo, S., Sigauque, B., O’Callaghan, C.T., Letang, E., Mandomando, I., Nhalungo, D., Quintó, L. and Alonso, P. (2009) Surveillance of Acute Bacterial Meningitis among Children Admitted to a District Hospital in Rural Mozambique. Clinical Infectious Diseases, 48, S172-S180.

[127] Fraser, D., Givon-Lavi, N., Bilenko, N. and Dagan, R. (2001) A Decade (1989-1998) of Paediatric Invasive Pneumococcal Disease in 2 Populations Residing in 1 Geographic Location: Implications for Vaccine Choice. Clinical Infectious Diseases, 33, 421-427. http://dx.doi.org/10.1086/321874

[128] Weisblum, B. (1995) Insights into Erythromycin Action from Studies of Its Activity as Inducer of Resistance. Antimicrobial Agents and Chemotherapy, 39, 797-805.

[129] Leclercq, R. and Courvalin, P. (2002) Resistance to Macrolides and Related Antibiotics in Streptococcus pneumoniae. Antimicrob Agents Chemother, 46, 2727-2734. http://dx.doi.org/10.1128/AAC.46.9.2727-2734.2002

[130] Fukuda, H. and Hiramatsu, K. (1999) Primary Targets of Fluoroquinolones in Streptococcus pneumoniae. Antimicrobial Agents and Chemotherapy, 43, 410-412.

[131] Gill, M.J., Brenwald, N.P. and Wise, R. (1999) Identification of an Efflux Pump Gene, pmrA, Associated with Fluoroquinolone Resistance in S. pneumoniae. Antimicrobial Agents and Chemotherapy, 43, 187-189.

[132] Connell, S.R., Tracz, D.M., Nierhaus, K.H. and Taylor, D.E. (2003) Ribosomal Protection Proteins and Their Mechanism of Tetracycline Resistance. Antimicrobial Agents and Chemotherapy, 47, 3675-3681. http://dx.doi.org/10.1128/AAC.47.12.3675-3681.2003

[133] Nikaido, H. (2009) Multidrug Resistance in Bacteria. Annual Review of Biochemistry, 78, 119-146. http://dx.doi.org/10.1146/annurev.biochem.78.082907.145923

[134] Padayachee, T. and Klugman, K.P. (1999) Molecular Basis of Rifampin Resistance in Streptococcus pneumoniae. Antimicrobial Agents and Chemotherapy, 43, 2362-2365. 
Scientific Research Publishing (SCIRP) is one of the largest Open Access journal publishers. It is currently publishing more than 200 open access, online, peer-reviewed journals covering a wide range of academic disciplines. SCIRP serves the worldwide academic communities and contributes to the progress and application of science with its publication.

Other selected journals from SCIRP are listed as below. Submit your manuscript to us via either submit@scirp.org or Online Submission Portal.
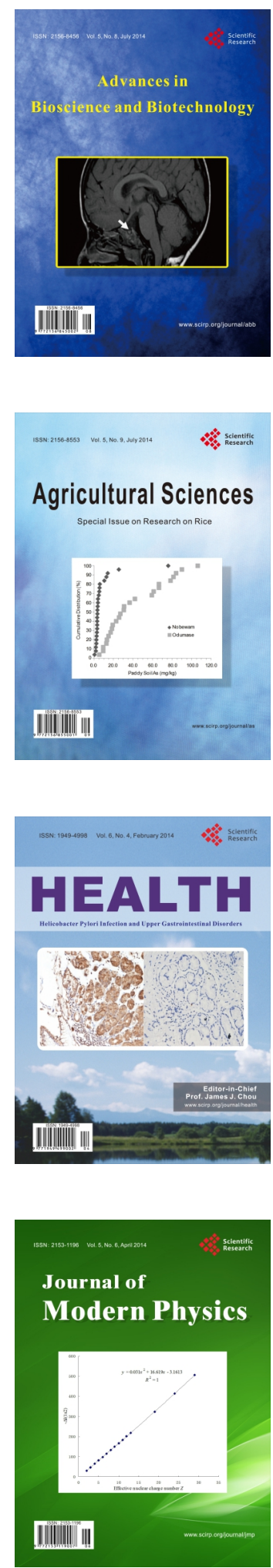
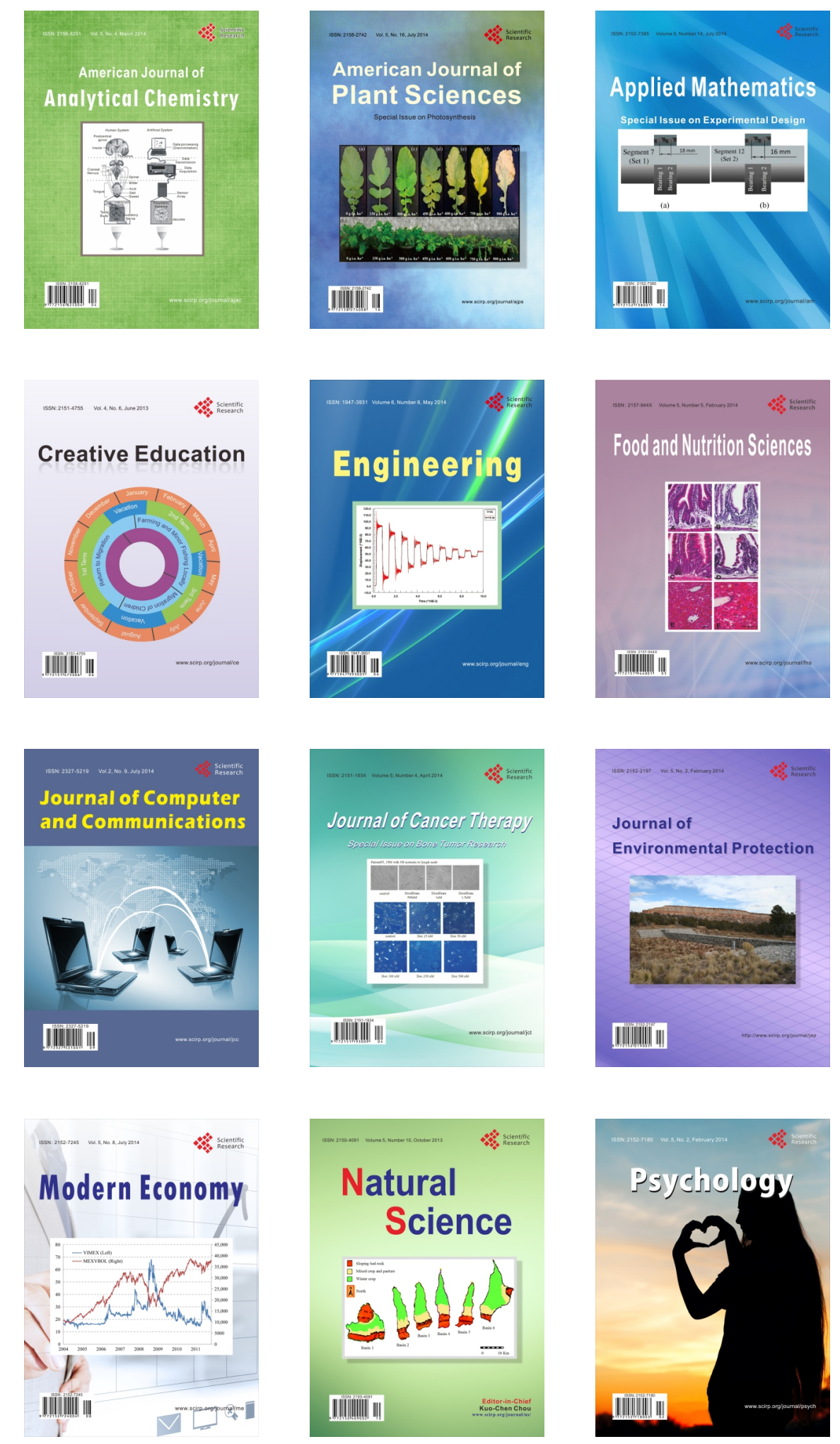